\title{
ANALISIS EFEKTIVITAS PELAYANAN PEMBUATAN \\ SURAT TANDA NOMOR KENDARAAN (STNK) DI \\ KANTOR SAMSAT KOTA DENPASAR
}

\author{
Brian Roy Monteiro \\ Universitas Pendidikan Nasional \\ brianmonteiro15@gmail.com
}

\begin{abstract}
ABSTRAK
Pada hakekatnya tugas pokok pemerintah sebagai organisasi publik adalah memberikan pelayanan kepada masyarakat. Demikian pula dengan SAMSAT Kota Denpasar, sebagai salah satu organisasi publik yang berhubungan langsung dengan pelayanan publik. Penelitian ini untuk mengetahui efektivitas pelayanan pembuatan STNK di kantor SAMSAT Kota Denpasar. Metode yang dikembangkan dalam penelitian ini adalah metode penelitian deskriptif, dengan pendekatan kualitatif. Yaitu metode yang menggambarkan kejadian yang ada dengan menggunakan pendekatan wawancara. Penelitian ini menyimpulkan bahwa dalam pelaksanaan pelayanan perpanjangan surat tanda nomor kendaraan di kantor sistem administrasi manunggal satu atap sudah maksimal. Pelayanan dalam perpanjangan surat tanda nomor kendaraan dinyatakan baik responden, saranan dan prasarana yang memadai serta kualitas sumber daya manusia yang sudah maksimal.
\end{abstract}

Kata Kunci : Efektivitas Pelayanan Pembuatan STNK 


\begin{abstract}
Basically the main task of the government as a public organization is to provide services to the community. Likewise, SAMSAT Denpasar City, as one of the public organizations that is directly related to public services. This study is to determine the effectiveness of the vehicle registration manufacturing service at the SAMSAT office in Denpasar. The method developed in this research is descriptive research method, with a qualitative approach. Namely a method that describes the events that exist using the interview approach. This study concludes that in the implementation of the service extension of the vehicle registration certificate in the one-stop administrative system office is maximum. The service in the extension of the vehicle registration certificate is stated by the respondent, adequate facilities and infrastructure as well as maximum quality human resources.
\end{abstract}

Keywords: Effectiveness of STNK Making Services

\title{
PENDAHULUAN
}

Negara berkewajiban melayani setiap warga negara untuk memenuhi hak dan kebutuhan dasarnya.Salah satunya yaitu memberikan pelayanan yang berkualitas. Untuk menyelenggaraan pelayanan publik diperlukan suatu norma hukum yang memberi pengaturan secara jelas, sebagai upaya untuk meningkatkan kualitas dan menjamin penyediaan pelayananpublik sesuai dengan asas-asas umum pemerintahan dan korporasi yang baik serta untuk memberi perlindungan bagi setiap warga negara dan penduduk dari penyalahgunaan wewenang di dalam penyelenggaraan pelayanan publik. Undang-Undang Nomor 25 Tahun 2009 tentang Pelayanan Publik mengatur tentang prinsip-prinsip pemerintahan baik yang merupakan efektivitas fungsi-fungsi pemerintahan itu sendiri.Pelayanan publik yang dilakukan oleh pemerintahan atau korporasi yang efektif dapat memperdalam kepercayaan pada pemerintahan dan administrasi publik.

Pada instansi-instansi dan organisasi yang mengutamakan pelayanan publik khususnya pelayanan pada masyarakat, pada proses dan praktek pelayanan yang harus diperhatikan yaitu tingkat kepuasan terhadap masyarakat, menyangkut masalah dalam hal ini ialah pelayanan publik dalam penerbitan Surat Tanda Kendaraan Bermotor (STNK). Surat Tanda Nomor Kendaraan Bermotor (STNK) diterbitkan oleh Sistem Administrasi Manunggal Satu Atap (SAMSAT) yakni tempat pelayanan penerbitan/pengesahan STNK oleh 3 (tiga) instansi yaitu Polri, Dinas Pendapatan Provinsi dan PT. Jasa Raharja. SAMSAT berfungsi sebagai sarana perlindungan masyarakat, sarana pelayanan masyarakat, sebagai deteksi guna membentuk langkah selanjutnya jika terjadi pelanggaran dan untuk meningkatkan penerimaan negara 
melalui sektor pajak.Dalam hal ini pihak kepolisian hanya berfungsi dalam penerbitan, perpanjangan dan pengesahan STNK.Untuk masalah pajak kendaraan beroda dua dan beroda empat diserahkan kepada Dinas Pendapatan Provinsi dan PT. Jasa Raharja. Dalam rangka peningkatan pelayanan STNK pada kenyataannya menghadapi berbagai kendala dalam pelaksanaan di lapangan. Keluhan masyarakat terhadap kondisi penyediaan pelayanan publik yang dikelola oleh Aparatur Negara khususnya pada pelayanan penerbitan STNK.

Pelayanan penerbitan STNK di berbagai wilayah di Indonesia masih terdapat banyak masalah pelayanan, mulai dari masalah tarif, penggunaan sistem online yang masih kurang efektif dengan alasan kegagalan jaringan sehingga sering menyebabkan lamanya penerbitan, dan kekosongan blanko, sehingga masyarakat mendapatkan STNK sementara yang hanya bisa digunakan paling lama 6 (enam) bulan, dan pelayanan STNK keliling yang hanya melayani

perpanjangan dan pengesahan. Pada hakekatnya pelayanan SAMSAT Kota Denpasar bertujuan untuk memberikan kepuasan masyarakat sebagai pengguna pelayanan SAMSAT Kota Denpasar sebagai salah satu instansi pemerintah daerah harus mampu melayani masyarakat secara maksimal dari penyelenggaraan pelayanan, kinerja aparat, dan mekanisme kerja yang ada. SAMSAT yang dalam hal ini merupakan penyelenggaraan pelayanan di sektor peningkatan, pengamanan dan penertiban pelaksanaan pemungutan pajak-pajak Daerah khususnya pemungutan pajak kendaraan bermotor (PKB) dan Bea Balik Nama Kendaraan Bermotor (BBN-KB) mempunyai tujuan untuk memudahkan masyarakat mendapatkan pelayanan. Salah satu hal penting yang perlu dilakukan dan diperhatikan oleh setiap perusahaan untuk dapat bertahan hidup dan berkembang adalah mempertahankan kualitas layanan terhadap kepuasaaan konsumen perusahaan. Kualitas layanan merupakan hal yang sangat penting untuk perusahaan jasa, untuk mempertahankan kualitas layanan perusahaan jasa harus senantiasa melakukan survei dari waktu ke waktu kepada konsumen untuk mengetahui apa yang diinginkan dan diharapkan terhadap perusahaan jasa selaku penyedia layanan.

\section{Rumusan Masalah}

Berdasarkan latar belakang penelitian maka rumusan masalah dalam penelitian ini adalah Bagaimana efektivitas pelayanan pembuatan STNK di kantor SAMSAT Denpasar? 


\section{Tujuan Penelitian}

Untuk mengetahui efektivitas pelayanan pembuatan STNK di kantor SAMSAT Denpasar.

\section{KAJIAN TEORI}

\section{Konsep Efektivitas}

Efektivitas menurut Mahmudi (2015:86) merupakan hubungan antara output dengan tujuan. Semakin besar kontribusi output terhadap pencapaian tujuan maka semakin efektif organisasi, program, atau kegiatan. Jika ekonomi berfokus pada input dan efesiensi pada output atau proses maka efektivitas berfokus pada outcome (hasil). Suatu organisasi, program, atau kegiatan dinilai efektif apabila output yang dihasilkan bisa memenuhi tujuan yang diharapkan. 1) Waktu.

Cepat tidaknya satuan kerja dalam suatu organisasi memberikan pelayanan kepada pelanggannya jelas merupakan suatu keriteria. Hanya saja penggunaan ukuran tentang cepat tidaknya pelayaan itu diberikan berbeda dari satu orang ke orang lain. Artinya, seseorang mungkin saja merasa bahwa dutinjau dari segi waktu, pelayanan yang diterimanya sudah memuaskan, sedangkan bagi orang lain waktu yang sama mungkin masih dirasakan terlalu lama. Terlepas dari penilaian subjektif, yang jelas ialah bahwa faktor waktu dapat dijadikan sebagai salah satu ukuran efektivitas dan efesiensi kerja organisasi .

2) Kecermatan.

Kecermatan dapat dijadikan ukuran. Dalam hal ini yang dimaksud ialah misalnya jika menurut pengalaman pelanggan yang diterimanya kurang dari yang seharusnya, maka ia akan cenderung memberikan nilai yang tidak terlalu tinggi terhadap afesiensi dan efektivitas kerja dari pihak yang bertanggung jawab memberikan pelayanan kepadanya meskipun diberikan dalam waktu singkat.

3) Gaya pemeberian layanan.

Gaya pemberian layanan merupakan salah satu ukuran lain yang dapat dan biasanya digunakan dalam mengukur efesiensi dan efektivitas kerja suatu organisas. Yang dimaksud dengan gaya disini adalah cara dan kebiasaan para karyawan dalam suatu organisasi memberikan jasa kepada pelanggannya. Tidak mustahil bahwa seorang pendatang baru disuatu 
tempat pada waktu menerima pelayanan oleh suatu organisasi tertentu merasa bahwa gaya pelayanan dari pihak yang memberikan pelayanan itu tidak sesuai dengan seleranya. Perasaan tidak sesuai itu merupakan hal yang subjektif sifatnya.

\section{METODE PENELITIAN}

\section{Lokasi Penelitian}

Lokasi penelitian ini berada di Kantor SAMSAT Jalan Kapten Tantular No.1 Renon Denpasar Selatan . Adapun alasan daerah ini dijadikan sebagai lokasi penelitian karena peneliti ingin mengetahui bagaimana efektivitas pelayanan pembuatan STNK di kantor SAMSAT Denpasar.Disamping itu juga lokasi penelitian ini dapat mempermudah peneliti untuk mengumpulkan data yang dibutuhkan.

\section{Jenis Penelitian}

Jenis penelitian ini adalah penelitian deskriptif dengan pendekatan kualitatif, yakni mendeskripsikan dan menyajikan hasil penelitian secara keseluruhan dan lengkap sesuai hasil penelitian.Penelitian deskriptif merupakan penelitian yang berusaha mendeskripsikan dan menginterpretasikan sesuatu.Menurut Furchan dalam Budiman (2011:90) bahwa penelitian deskriptif adalah penelitian yang dirancang untuk memperoleh informasi tentang status suatu gejala saat penelitian dilakukan.

\section{Jenis Data}

Data menurut jenisnya dibagi menjadi 2 (dua) macam, yaitu data kualitatif dan data kuantitatif.

\section{Informan Penelitian}

Menurut Faisal dalam suryo dan Dwi anggraeni (2011:66) konsep sampel dalam penelitian kualitatif berkaitan dengan bagaimana memilih informan atau situasi social tertentu yang dapat memberikan informasi yang akurat yang terpercaya mengenai elemen - elemen yang ada. Pengambilan sampel dalam penelitian kualitatif biasanya menggunakan purposive sampling dengan berbagai pendekatan yang paling representatif untuk penelitian kualitatif. Adapun syarat yang harus terpenuhi dalam memilih informan, yaitu : 
1. Iinforman masih berkecimpung atau terlibat dalam kegiatan yang diteliti;

2. Informan memiliki waktu yang memadai untuk memberikan informasi;

3. Informan menguasai dan memahami proses enkulturasi sehingga informasi yang diberikan bukan sekedar diketahui tetapi juga dihayati;

4. Informan dalam menyampaikan informasi tidak menyampaikan informasi hasil kemasannya sendiri.

Dari syarat diatas, adapun penentuan informan dalam penelitian ini adalah pihak pihak yang dapat memberikan informasi kepada peneliti. Sasaran informan yang diambil oleh peneliti yaitu:

1. Kepala Dinas kantor SAMSAT Kota Denpasar : 1 orang

2. Staff Kantor SAMSAT : 5 orang

3. Masyarakat yang datang mengurus STNK : 5 orang

\section{PEMBAHASAN}

\section{a. Analisis dalam menanggapi indicator Tangibles terhadap Efektivitas PelayananPembuatan STNK di Kantor SAMSAT}

Dari hasil penelitian di lapangan menunjukan aparatur Kantor SAMSAT dan pengguna jasa bahwa pelaksanaan pelayanan dalam aspek bukti langsung atau tampilan fisik sudah optimal oleh sarana dan prasarana yang mendukung. Sarana dan prasarana merupakan salah satu indikator yang penting dalam pelaksanaan pelayanan. Kedisiplinan aparatur pelayanan juga sangat penting, ini menyangkutkualitas sumber daya manusia yang melaksanakan pelayanan. Menurut Serverqual; Tangibles atau bukti fisik yaitu kemampuan suatu perusahaan/lembaga dalam menunjukkan eksistensinya kepada pihak eksternal. Penampilan dan kemampuan sarana dan prasarana fisik perusahaan dan keadaan lingkungan sekitarnya adalah bukti nyata dari pelayanan yang diberikan oleh pemberi jasa. Yang meliputi fasilitas (gedung dan lain sebagainya), perlengkapan dan peralatan yang digunakan (teknologi, serta penampilan pegawainya.) 
Analisi penelitian ini menganalisa bahwa terlihat dari segi tampilan fisik sarana dan prasarana dinilai sangat baik oleh pihak pengguna jasa, sepeni contoh bukti fisik sarana dan prasarana yang penulis amati tersedia di kantor SAMSAT Kota Denpasar antara lain : dua buah gedung lantai II yang merupakan Kantor SAMSAT Induk, beserta dengan fasilitas pendukungnya. Untuk memperlancar pelayanan kepada masyarakat pengguna jasa didukung dengan berbagai peralatan seperti :

1. PC (Komputer)

2. Printer

3. Telepon

4. Genset

5. $\mathrm{AC}$

6. Mesin Ketik

7. Mesin Hitung

8. Wifi

9. Nomor antri digital

10. Papan informasi

\section{b. Analisis dalam menanggapi indicator Reliabilty terhadap Efektivitas Pelayanan Pembuatan STNK di Kantor SAMSAT}

Dari hasil penelitian di lapangan menunjukan terlihat antara tanggapan dari pihak SAMSAT dengan pengguna jasa sependapat dalam menilai ketepatan dalam melayani, ini bisa dikatakan bahwa pelayanan di Kantor SAMSAT dalam hal pembuatan Surat Tanda Nomor Kendaraan (STNK) mengenai ketepatan dalam pemberian pelayanan sudah efektif untuk pengguna jasa. Penulis menganalisa bahwa soal kecepatan proses pelayanan STNK di kantor SAMSAT Kota Denpasar sudah sangat baik untuk kantor pelayanan publik tingkat Kota/kabupaten. Dilihat dari SOP yang diterapkan oleh pihak aparatur dalam melayani para penguna jasa, seperti hasil wawancara tertuju ke pihak pengguna jasa menyampaikan bahwa kecepatan proses pelayanan masih dibatas normal/wajar. Terkadang terdapat masalah sistem kerja di komputer yang mengalami gangguan sehingga menghambat proses pelayanan, tetapi 
masih dapat dimaklumi dari sebagaian pihak karena hambatan tersebut timbul diluar kelalaian aparatur. SOP yang dimaksud penulis merupakan faktor yang sangat penting dalam membantu memperlancar kerja pihak aparatur. Kemudian soal ketepatan proses pelayanan dapat dilihat di lapangan bahwa sistem kerja di kantor SAMSAT sudah tertata dengan baik mulai dari proses permohonan/pendaftaran hingga proses paling terakhir yaitu pengarsipan bahwa petugas aparatur sudah terbagi dalam kelompok kerja yang memiliki tugasnya masing-masing, yang dapat dilihat dari beberapa loket-loket yang memiliki fungsi untuk melayani penguna jasa secara tepat waktu.

Menurut Serverqual, Reliability atau keandalan yaitu kemampuan organisasi untuk memberikan pelayanan sesuai yang dijanjikan secara akurat dan terpercaya. Kinerja harus sesuai dengan harapan pelanggan yang berarti ketepatan waktu, pelayanan yang sama untuk semua pelanggan tanpa kesalahan, sikap yang simpatik, dan dengan akurasi yang tinggi. Analisa penelitian ini menganalisa bahwa dari segi kecepatan proses pelayanan pihak pegawai menerapkan standar waktu pelayanan terhitung mulai diterimanya berkas permohonan yang telah dinytakan lengkap sesuai dengan persyaratan STNK.

\section{Prosedur Penerbitan STNK}

Prosedur penerbitan STNK dilaksanakan melalui kelompok kerja :

a. Pendaftaran, pendataan dan verifikasi;

b. Penetapan;

c. Pencetakan dan pengesahan;

d. Penyerahan;

e. Pengarsipan.

\section{c. Analisis dalam menanggapi indikator Responsivess terhadap Efitivitis Pelayanan Pembuatan STNK di Kantor SAMSAT}

Dari hasil penelitian di lapangan, dapat kita dilihat bahwa pelayanan dalam aspek kesadaran dan ketanggapan dalam pemberian pelayanan juga sudah optimal, inibisa dikatakan dari kualitas sumber daya manusia yang semakin membaik. Profesionalisme yang sangat diharapkan oleh para pengguna jasa sudah dirasakan sepenuhnya sehingga tidak menimbulkan 
beberapa keluhan-keluhan dari pengguna jasa seperti informasi mengenai syarat dalam mengurus STNK. Maka ini sebaiknya dipertahankan supaya lebih mampu dan siap untuk melayani masyarakat sepenuhnya. Menurut Serverqual, Responsiveness atau ketanggapan yaitu suatu kemampuan untuk membantu dan memberikan pelayanan yang cepat (responsif) dan tepat kepada pelanggan, dengan penyampaian informasi yang jelas. Membiarkan pengguna jasa menunggu tanpa adanya suatu alasan yang jelas menyebabkan persepsi negatif dalam kualitas pelayanan.

Analisa penelitian ini menganalisa bahwa dari segi aspek kesadaran dan ketanggapan dalam hal meneliti kelengkapan dokumen persyaratan penerbitan STNK seperti :

1) Meneliti/Mencocokan kelengkapan dokumen persyaratan penerbitan STNK bam yaitu, kelengkapan dokumen persyaratan wajib di lampirkan sesuai ketentuan dan diteliti mengunakan check list persyaratan penerbitan STNK baru secara manual.

2) Meneliti kelengkapan dokumen persyaratan perpanjangan STNK yaitu, kelengkapan dokumen persyaratan wajib dilampirkan sesuai ketentuan danditeliti mengunakan check list persyaratan penerbitan STNK perpanjangan secara manual.

3) Meneliti kelengkapan dokumen persyaratan pengesahan STNK yaitu, kelengkapan dokomen persyaratan wajib dilampirkan sesuai ketentuan dan diteliti mengunakan check list persyaratan pengesahan STNK secara manual.

4) Meneliti kelengkapan dokumen persyaratan penerbitan STNK perubahan identitas ranmor atau pemilik dan pemindah tanganan kemilikan yaitu, kelengkapan dokumen persyaratan wajib dilampirkan sesuai ketentuan dan diteliti menggunakan check list persyaratan perubahan identitas dan pemindah tanganan kepemilikan secara manual.

5) Meneliti kelengkapan dokumen persyaratan penerbitan STNK hilang atau rusak yaitu, kelengkapan dokumen persyaratan wajib dilampirkan sesuai ketentuan dan diteliti mengunakan check list persyaratan STNK hilang/rusaksecara manual.

\section{d. Analisis dalam menanggapi indikator Assurance terhadap Efektivitas Pelayanan Pembuatan STNK di Kantor SAMSAT}

Dari hasil penelitian di lapangan, menunjukan bahwa dalam kemampuan, sikap, dan kepercayaan para pengguna jasa kepada para aparatur kantor SAMSAT terhadap keluhan- 
keluhan dirasa masih kurang maksimal. Sehingga apapun keluhan yang disampaikan oleh para pengguna jasa masih belum adapengaplikasian di lapangan. Hal ini menimbulkan keluhan oleh para wajib pajak yangmenikmati layanan di Kantor SAMSAT khususnya yang melaksanakan pembuatan STNK.

Penulis menganalisa soal pengetahuan yang dimiliki pegawai sebagai pelaksana pelayanan dalam melaksanakan tugas sudah cukup baik atau mumpuni. Dilihat dari setiap pegawai benar-benar menguasai masing-masing prosedur yang ada sehingga apabila ada beberapa penguna jasa yang tidak mengerti bagaimana untuk menyelesaikan suatu masalah yang dialami, maka disanalah petugas mampu menjelaskan secara langsung apa yang harus dilakukan pihak penguna jasa tersebut. Contoh kecil yang penulis temui di lapangan, seorang penguna jasa terlihat sangat kebingungan karena baru pertama kali mengurus STNK kemudian langsung dihampiri seorang petugas untuk diarahkan ke loket yang ada. Pengetahuan pegawai pada dasarnya memang suatu kewajiban yang harus dimiliki seorang aparatur pelaksana pelayanan publik dan sejak awal sudah dibekali pelatihan-pelatihan khusus untuk menguasai semua proses dan prosedur untuk nantinya diimplementasikan.

Selain pengetahuan pegawai, penulis menganalisa soal sikap, keramahan dan kepercayaan yang ditunjukkan oleh pihak aparatur kepada pihak penguna jasa belumlah maksimal. Dari apa yang penulis analisa soal sikap petugas yang kurang maksimal tersebut menimbulkan rasa hak seorang penguna jasa tidak terpenuhi. Sehingga pihak penguna jasa merasa kebingungan dan lebih memilih untuk menyerahkan berkas kepada biro jasa. Kemudian keramahan petugas yang penulis amati langsung, juga belum maksimal ditunjukkan secara menyeluruh oleh pihak aparatur. ada beberapa aparatur yang sudah maksimal dan ada juga yang belum maksimal sesuai harapan pengguna jasa. Dari sikap dan keramahan yang belum maksimal tersebut dapat dilihat bahwa pihak penguna jasa kurang mempercayai pegawai/aparatur dalam melayani pihak penguna jasa secara baik

Menurut Serverqual, Assurance atau jaminan dan kepastian yaitu pengetahuan, kesopansantunan, dan kemampuan para pegawai perusahaan untuk menumbulkan rasa percaya para pelanggan kepada perusahaan. Terdiri dari beberapa komponen antara lain, komunikasi (communication), kredibilitas (credibility), keamanan (security), kompeten (competence), dan sopan santun (courtesy). 


\section{e. Analisis dalam menanggapi indikator Empathy terhadap Efektivitas Pelayanan Pembuatan STNK di Kantor SAMSAT}

Dari hasil penelitian di lapangan, menunjukan bahwa dalam dimensi initerlihat keinginan masyarakat yang sepenuhnya hampir terlaksana, hanya saja belumbenar-benar optimal, kesadaran para aparatur mengenai tata cara dalam pemberian pelayanan masih kurang baik. Empati adalah kemampuan petugas dalam merespon keinginan wajib pajak bahkan yang tak terucap sekalipun. Kemampuan ini dipandang sebagai kunci menaikan intensias dan kedalaman hubungan petugas dengan wajib pajak (connecting with). Karena dari indikator empati ini dapat melihat suatu pelayanan itu berkualitas atau tidak. Sikap dari para petugas menunujukkan kemauan aparat sebagai pelayanan publik dalam melayani kebutuhan masyarakat. Sikap itu antara lain ramah, sopan santun, mendahulukan kepentingan setiap pemohon atau penerima layanan yang datang, menghargai setiap penerima layanan serta bersikap adil atau tidak diskriminatif terhadap setiap pemohon yang datang.

Menurut Serverqual, Empathy yaitu mamberikan parhatian yang tulus danbersifat individual atau pribadi yang diberikan kepada para pelanggan dengan berupa memahami keinginan konsumen. Setiap kegiatan atau aktivitas pelayanan memerlukan adanya pemahaman dan pengertian dalam kebersamaan asumsi atau kepentingan terhadap suatu hal yang berkaitan dengan pelayanan. Pelayanan akanberjalan dengan lancar dan berkualitas apabila setiap pihak yang berkepentingan dengan pelayanan memiliki adanya rasa empati (empathy) dalam menyelesaikan atau mengurus atau memiliki komitmen yang sama terhadap pelayanan (Parasuraman,2009:40).

Faktor yang menjadi penghambat dalam pelaksanaan pelayanan publik di bidang STNK dikelompokkan menjadi dua, yaitu : pertama, faktor internal birokrasi publik, kedua faktor eksternal, yakni berupa dinamika masyarakat dan tumbuh kembangnya masalah yang dihadapi masyarakat sebagai pihak yang dilayani. Masalah yang dihadapi aparatur pemerintah daerah, baik yang berasal dari lingkungan internal maupun eksternal muaranya lebih banyak diarahkan pada kinjera, aparatur pemerintah daerah dalam menjalankan tugas yang diamanakan kepadanya. Faktor lingkungan internal birokrasi bisa berupa situasi dan kondisi baik berupa organisasi (struktur, penempatan, personel, efektifitas kegiatan) efektifitas komunikasi antar 
unit, sumber daya dan pemberdayaannya. Sementara itu, factor penghambat dari lingkungan eksternal berupa situasi dan kondisi di sekeliling organisasi yang berpengaruh terhadap kelancaran pelaksanaan pelayanan publik.

\section{KESIMPULAN}

Berdasarkan hasil penelitian dan pembahasan yang telah dipaparkan sebelumnya, maka dapat ditarik kesimpulan bahwa : Pada dasarnya pelayanan yang baik sangat menentukan tingkat kepuasan. dapat dirasakan setelah menerima jasa dari organisasi pelayanan. Jika pelayanan yang diberikan sesuai dengan apa yang diharapkan oleh masyarakat maka pelayanan tersebut dapat dikatakan memuaskan tetapi sebaliknya jika pelayanan itu tidak seperti apa yang diharapkan maka pelayanan tersebut dinilai tidak memuaskan, sehingga sebagai organisasi pelayanan perlu memperhatikan kualitas pelayanannya termasuk SAMSAT Kota Denpasar. Dari hasil penelitian secara keseluruhan efektivitas pelayanan SAMSAT dapat dikatakan sudah memenuhi harapan masyarakat sebagai pengguna jasa. Hal ini dapat dilihat dari :

\section{a. Bukti Langsung (Tangibles)}

Bukti langsung pelayanan SAMSAT dapat dilihat dari sarana kerja yang ada, tata ruang kantor dan fasilitas pelayanan yang dimilik kantor SAMSAT Kota Denpasar dinilai sudah cukup dan sudah memenuhi standar kantor pelayanan publik tingkat Kota/kabupaten.

\section{b. Kehandalan (Reliability)}

Kehandalan pegawai SAMSAT dalam memberikan pelayanan kepada pengguna jasa sudah cukup memuaskan, hal ini dapat dilihat pada kecepatan, ketepatan dan kemauan pegawai dalam memberikan pelayanan kepada pengguna jasa sudah maksimal, salah satunya yang dapat dirasakan langsung pihak pengguna jasa bahwa sistem kerja yang tertata dengan baik sangat menentukan waktu yang efesien dalam mengurus STNK.

\section{c. Daya Tanggap (Responsivenes)}

Jika dilihat dari daya tanggap dalam menanggapi keluhan pengguna jasa, pegawai SAMSAT sudah memberikan tanggapan yang memuaskan bagi pengguna jasa, selain itu jika ada keluhan yang disampaikan secara langsung sudah segera direspon oleh apartur kantor SAMSAT Kota Denpasar. 


\section{d. Jaminan (Assurance)}

Dilihat dari kemampuan karyawan atas pengetahuan terhadap segala aspek mengenai proses pembuatan STNK sudah tepat, hanya saja kualitas keramah tamahan dan kesopanan para aparatur yang perlu diperhatikan dan ditingkakan lagi dalam memberikan pelayanan agar pihak pengguna jasa merasa lebih nyaman dan mempercayaai kualitas pihak aparatur dalam melaksanakan tugasnya.

\section{e. Empati (Emphaty)}

Perhatian secara individual yang diberikan Petugas SAMAT terhadap pengguna jasa, seperti kemampuan petugas dalam berkomunikasi, sikap dan motivasi dengan pengguna jasa untuk memahami keinginan dan kebutuhan pengguna jasa sudah cukup baik.

\section{DAFTAR PUSTAKA}

Dwiyanto, Agus. 2006. Mewujudkan Good Governance Melalui Pelayanan Publik. Yogyakarta: UGM Press.

Harbani Pasolong, Sinambela. 2011. Teori Pelayanan Publik. Jakarta: PT. Bumi Aksara.

Pasolong. 2011. Kualitas Manajemen Pelayanan. Jakarta: STIA LAN Press.

Mahmudi. 2015. Manajemen Kinerja Sektor Publik. Yogyakarta: UPP STIM YKPN.

Moleong, Lexy J. 2012. Metodologi Penelitian Kualitatif. Bandung: PT. Remaja Rosdaarya.

Moenir, H. A. S. 2011. Manajemen Pelayanan Umum di Indonesia. Jakarta: Bumi Aksara. Pasolong. 2011.Teori Administrasi Publik. Makassar: Arbeta.

Siagian, Sondang P. 2006. Eksekuti yang Efektif. Jakarta: Gunung Agung.

Sugiyono. 2009. Metode Penelitian Administrasi. Bandung: Alfabeta. Bandung: Alfabeta.

Sugiyono. 2012. Metode Penelitian Kuantitatif Kualitatif Dan R\&D. Bandung : Alfabeta

Sugiyono. 2013. Metode Penelitian Kuantitatif, Kualitatif dan $R \& D$.Bandung.

Sugiyono. 2014. Metode Penelitian Kuantitatif, Kualitatif dan $R \& D$. Bandung: Alfabeta

Sugiyono.2015. Memahami Penelitian Kualitatif. Bandung : Alfabeta. 


\section{Peraturan Perundang-Undangan}

Undang - Undang Dasar 1945

Undang - Undang Nomor 12 Tahun 2008 Tentang Pemerintah Daerah

Undang - Undang Nomor Nomor 25 Tahun 2009 Tentang Pelayanan Publik

Kepmen PAN Nomor 25 Tahun 2004 Tentang Penyelenggaraan Pelayanan

Kepmen PAN Nomor 63 Tahun 2004 Tentang Standar Pelayanan Publik 